International Journal of Health Sciences
Available online at www.sciencescholar.us
Vol. 5 No. 3, December 2021, pages: $503-512$
e-ISSN: 2550-696X, p-ISSN: 2550-6978
https://doi.org/10.53730/ijhs.v5n3.2116

\title{
Determinant of Child Obesity in COVID-19 Pandemic and Analysis of Intervention Requirement
}

\author{
I Putu Suiraoka a ${ }^{\text {, Hertog Nursanyoto }}{ }^{\mathrm{b}}$, Ni Made Ayu Suastiti ${ }^{\mathrm{c}}$ \\ Manuscript submitted: 21 June 2021, Manuscript revised: 15 September 2021, Accepted for publication: 9 November 2021
}

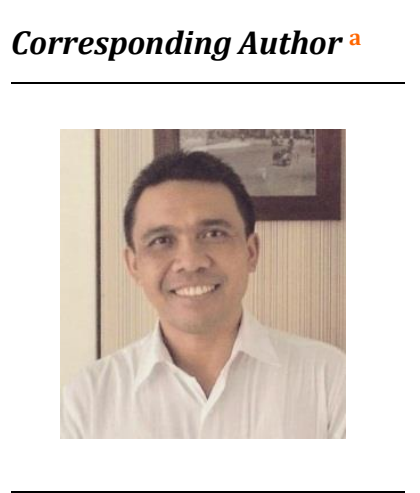

\section{Keywords}

basic health; health care system; health challenges; health problem; health sector; nutrition care; obesity;

\begin{abstract}
The shift in diet and physical activity in modern society has resulted in obesity becoming a public health problem. This problem will be a burden to the state if it is not addressed early on. This study aims to examine and find models of obesity determinants based on consumption, physical activity, lifestyle, social and environmental factors. The sample was randomly selected for elementary school children in the city of Denpasar. The collected data were analyzed by using a structural equation model. Of the 375 elementary school children in the city of Denpasar, it is known that 35.5\% are overweight, even one-third of them have entered the obesity stage. Consumption factors have the dominant contribution in increasing the risk of obesity. In the next order, other factors emerged: social factors; lifestyle; physical activity; followed by environmental factors. As a follow-up plan from the results of this study, a Digital-Based Nutrition Care Process for Obese Children will be designed which can later be disseminated on all mass line platforms as an intervention plan. Although the application is designed to be disseminated through the mass line platform, the role of the teacher is still needed to monitor the progress of this program.
\end{abstract}

International Journal of Health Sciences (c) 2021. This is an open access article under the CC BY-NC-ND license (https://creativecommons.org/licenses/by-nc-nd/4.0/).

\section{Contents}

Abstract

1 Introduction

2 Materials and Methods

3 Results and Discussions

4 Conclusion.

\footnotetext{
a Poltekkes Kemenkes Denpasar, Denpasar, Indonesia

b Poltekkes Kemenkes Denpasar, Denpasar, Indonesia

c Poltekkes Kemenkes Denpasar, Denpasar, Indonesia
} 


\section{Introduction}

Obesity in children is one of the most serious public health challenges in the 21st century. This problem is experienced almost all over the world in many low- and middle-income countries, especially in urban areas. WHO states that obesity is a global pandemic that occurs in both developed and developing countries. More than $50 \%$ of obese people live in ten countries in the world, Indonesia is one of them. The prevalence of obesity in children aged 5-12 years is $18.8 \%$ (Riskesdas, 2013). This figure shows an increase of 9.2 percent compared to the 2010 Riskesdas data.

The increasing prevalence of obesity is a burden for society and the country. For example, in the United States, this country spends 99.9 billion dollars annually to treat obesity (Chaput et al., 2011). The consequences of obesity place a significant burden both on health and quality of life as well as on the health care system at the individual and societal levels (Kovács et al., 2014). The prevalence of obesity in Indonesia continues to increase from year to year. The prevalence in the population aged 15 years and over is $2.5 \%$ consisting of $2.9 \%$ male and $2.0 \%$ female. Meanwhile, in Bali Province, the prevalence of obesity at the age of 13-15 years is 3.1\%. (Health Research and Development Agency, 2010) Based on the 2013 Basic Health Research Data, the prevalence of obesity in children aged 13-15 years in Indonesia is 10.8 percent, consisting of $8.3 \%$ overweight and $2.5 \%$ very obese. Bali Province is one of the provinces with obesity prevalence above the national level. (Health Research and Development Agency, 2013). Denpasar City is one of the cities with a high prevalence of obesity, including in the group of children (Health Research and Development Agency, 2013). The prevalence of obesity in Denpasar tends to increase sharply, from $11 \%$ in 2002 to $21.7 \%$ in 2010 (Adhianto \& Soetjiningsih, 2002; Yoga \& Sidiartha, 2010).

Obesity in childhood has a high risk of becoming obese in adulthood and has the potential to experience metabolic and degenerative diseases in the future (WHO, 2000; Heird, 2002; Kasiman, 2011). Obesity in children and adolescents is associated with adverse metabolic and cardiovascular traits (Baker et al., 2007; Daniels \& Greer, 2008), asthma exacerbations (Beuther et al., 2006), low self-esteem (French et al., 1995), and an increased likelihood of becoming obese in adulthood (Power, 1997; Whitaker et al., 1997). Obesity in childhood is strongly associated with family variables, including parental obesity, higher socioeconomic status, parental education, family size, and family activity patterns (Berhman, 1999). Damayanti (2008), describes various factors that cause obesity in children, including children's diet, level of physical activity, family factors, child psychology, and genetic factors.

Changes in diet and physical activity in modern society make obesity a difficult problem to overcome. Because obesity is a complex problem and the causes are multi-factorial, making it difficult to manage. Obesity is an important problem in public health, both in developed and developing countries. However, the determinants of obesity are different in different regions and cultures (Skinner \& Foster, 2013). Based on the description above, it is necessary to conduct a study that explores in more depth and finds a determinant model of obesity in elementary school children based on consumption, physical activity, lifestyle, social and environmental factors in Denpasar City. The purpose of this study is to analyze the factors that are the determinants of childhood obesity during the COVID-19 pandemic and examine the need for intervention (Barlow \& Minns, 2000).

\section{Materials and Methods}

This research is an observational study with a cross-sectional design. The population in this study were elementary school students in Denpasar City with the target population being elementary school students in the two sub-districts selected as research locations, namely East Denpasar and South Denpasar districts. After a random selection of 6 primary schools each in a predetermined area. The sample was selected based on the questionnaire form that was returned after being circulated through the mass line platform. From this kind of sample selection stage, there are 375 samples whose forms are complete and their obesity status can be determined (Ningsih \& Indriani, 2021). They are then used as the unit of analysis in this study. The research 
instrument consisted of a digital scale to measure body weight; a microtoise to measure height and a questionnaire form to explore the factors that trigger obesity. Data collection was carried out both face-to-face for anthropometric measurements to determine the nutritional status of the sample and online for the obesity risk factor questionnaire form filled out by respondents (parents of students).

The results of anthropometric measurements are then processed concerning the Minister of Health Regulation No. 2 of 2020 to determine obesity status according to BMI/U criteria for school-age children and adolescents (Reilly \& Dorosty, 1999; Vanderhoof \& Langnas, 1997). The z score obtained from the results of determining obesity status is then treated as the dependent variable (y) in multiple linear regression analysis. The analysis was carried out using the structural equation model in two stages, namely: 1) The factor confirmatory analysis stage to select the feasibility indicators of the five factors studied to be included in the structural equation model; 2) Choose the fittest structural equation model to explain the relationship between obesity and the five factors that are thought to trigger the problem. From the results of the analysis of the structural equation model, it is known what factors have the greatest contribution in triggering the obesity problem (Kusumajaya, 2021; Widana et al., 2021).

\section{Results and Discussions}

This research was conducted by taking subjects in several elementary schools in East Denpasar District, South Denpasar. The samples were students who were in Class IV, V, and VI. While the respondents are the father/mother/guardian of the sample who filled out the questionnaire distributed online by the researcher. During the study, 375 respondents returned the questionnaire in a filled state. Their complete characteristics are presented in Table 1.

Table 1

Characteristics of respondents

\begin{tabular}{llrr}
\hline Variable & Category & $\mathrm{f}$ & \multicolumn{1}{c}{$\%$} \\
\hline Age Group (years) & $20-29$ & 26 & 6.9 \\
& $30-39$ & 191 & 50.9 \\
& $40-49$ & 137 & 36.5 \\
& $>50$ & 21 & 5.7 \\
Education level & Primary school & 52 & 13.9 \\
& Junior high school & 24 & 6.4 \\
& Senior High School & 146 & 38.9 \\
& Diploma & 66 & 17.6 \\
& Bachelor & 68 & 18.1 \\
Family Relationship with sample & Postgraduate & 19 & 5.1 \\
& & & \\
& Father & 130 & 34.7 \\
Job type & Mother & 222 & 59.2 \\
& Guardian & 23 & 6.1 \\
& Government employees & 38 & 10.1 \\
& Private employees & 105 & 28.1 \\
& Entrepreneur & 68 & 18.1 \\
Total & Trader & 27 & 7.2 \\
& Laborer & 18 & 4,8 \\
& Not working & 119 & 31,7 \\
& & 375 & 100.0 \\
\hline
\end{tabular}

Suiraoka, I. P., Nursanyoto, H., \& Suastiti, N. M. A. (2021). Determinant of child obesity in COVID-19 pandemic and analysis of intervention requirement. International Journal of Health Sciences, 5(3). https://doi.org/10.53730/ijhs.v5n3.2116 
As shown in table 1, more than half of them (59\%) are mothers of the sample, but there is also a small proportion (6\%) of respondents who are guardians of the sample. Most of them are aged 30 - 39 years, working as private employees or not working and most of them are educated up to high school level. While the sample is at most 10 years old, more women, and mostly sitting in class IV (Table 2).

Table 2

Sample characteristics

\begin{tabular}{llrr}
\hline Variable & Category & $\mathrm{f}$ & $\%$ \\
\hline Gender & Boys & 172 & 45,9 \\
& Girls & 203 & 54,1 \\
Class & & 140 & 37,3 \\
& IV & 122 & 32,5 \\
& V & 113 & 30,2 \\
Age (years) & VI & & \\
& & 9 & 2,4 \\
& 8 & 107 & 28,5 \\
& 9 & 132 & 35,2 \\
Total & 10 & 108 & 28,8 \\
& 11 & 19 & 5,1 \\
& 12 & 375 & 100,0 \\
\hline
\end{tabular}

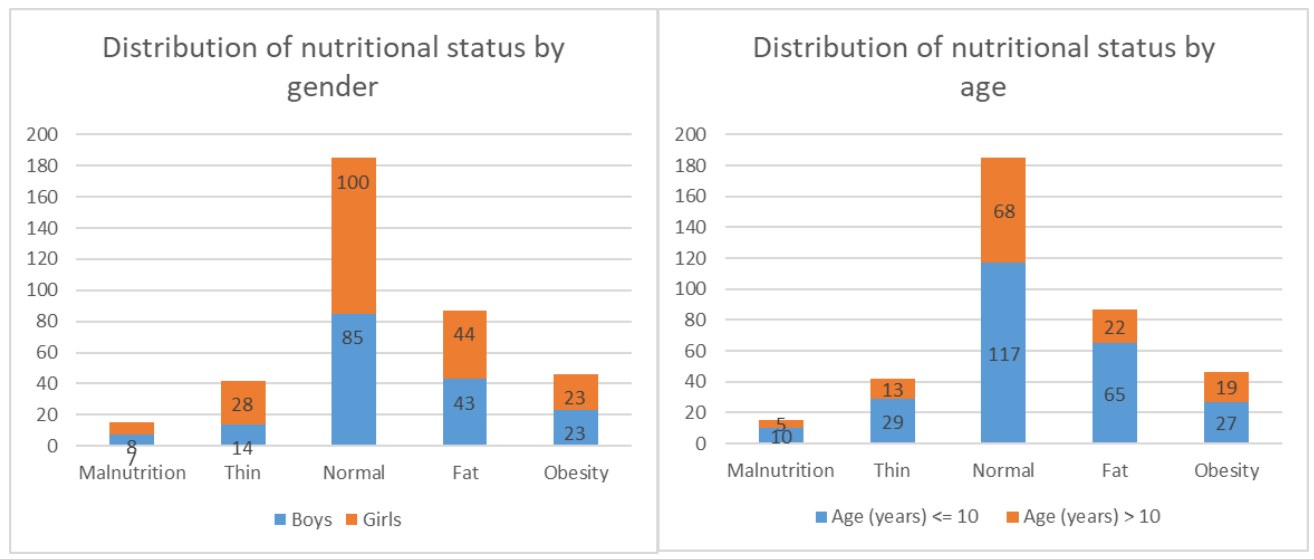

Figure 1. Distribution of sample nutritional status

Based on the results of the nutritional status assessment using the WHO reference standard for the BMI/U index, it is known that most of the samples have normal nutritional status. However, as shown in Figure 3, the phenomenon of "double burden of nutritional problems" is also clearly illustrated in the research sample. On the one hand, there were still $15.2 \%$ of samples with poor or poor nutritional status, and on the other hand, samples that were overweight and obese had a higher proportion and even doubled (35.5\%). When viewed by gender, the male sample group is more overweight, whereas the female sample group is more malnourished. Meanwhile, when viewed based on age, it appears that the problem of excess nutrition is more common in the sample group aged 10 years (Isenring et al., 2012).

\section{Structural equation model}

In this study, the triggers of obesity in children were examined in 5 constructs, namely consumption factors, physical activity, lifestyle, social, and environment. Each construct has a different number of indicators with full details presented in table 3. 
Table 3

Total indicators assumed to trigger obesity problems in elementary school children

\begin{tabular}{lccc}
\hline \multirow{2}{*}{ Construct } & \multicolumn{3}{c}{ Total Indicator } \\
\cline { 2 - 4 } & Full Model & Confirmatory Factor Analysis & Full Model \\
\hline Consumption & 19 & 8 & 4 \\
Physical Activity & 10 & 7 & 2 \\
Lifestyle & 6 & 5 & 2 \\
Social & 7 & 5 & 2 \\
Environment & 7 & 5 & 2 \\
Total Indicator & 49 & 30 & 12 \\
\hline
\end{tabular}

As presented in table 1, the total indicators that were asked as questions in the questionnaire were 49 items. However, from the results of the cohesiveness test of the constructor-forming indicators based on the confirmatory factor analysis, it was found that as many as 30 indicators deserve to be included in the full regression modeling with details of 8 indicators coming from the consumption factor construct; as many as 7 indicators come from the Physical Activity construct; and 5 indicators each of the Lifestyle, Social and Environmental constructs. The complete regression model is presented in Figure 2

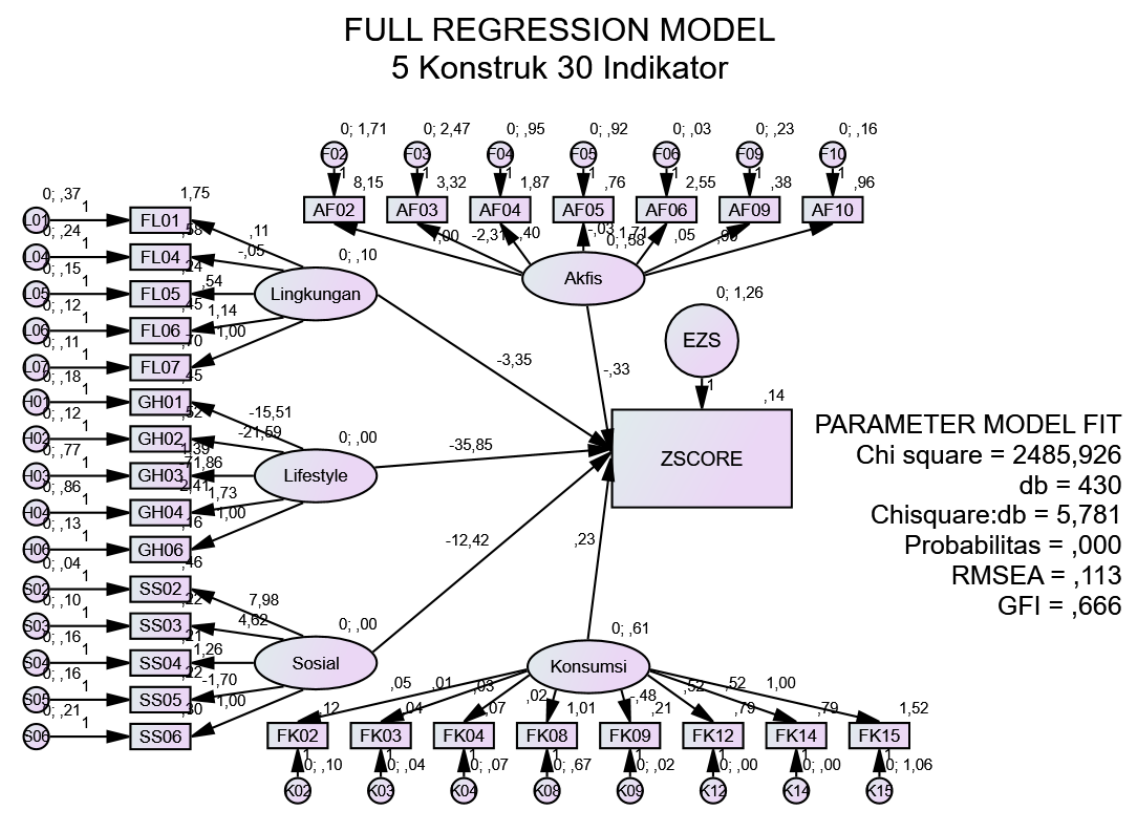

Figure 2. Complete regression model for obesity risk analysis based on consumption factors, physical activity, lifestyle, social and environmental factors

As shown in Figure 2, a complete regression consisting of 49 indicators results in an overidentified model and is still far from the ideal requirements for model fit parameters (RMSEA $\leq 0.08$ and GFI $\geq 0.90$ ). The value of the chi-square model is also still too large $(\chi 2=2485.926$; $p=0.00)$.

From the results of the analysis, it is known that the reduction of indicators with the backward method only reaches the ideal norm of model fit parameters, while in the regression model there are only 13 indicators. Even then, the value of the chi-square model is still large $((\chi 2=265.117 ; p=0.00)$. Even when the indicator reduction process has reached the limit, each construct only leaves 2 indicators, the value of the chisquare model is still too large. $(\chi 2=81,787 ; p=0,00)$.

Suiraoka, I. P., Nursanyoto, H., \& Suastiti, N. M. A. (2021). Determinant of child obesity in COVID-19 pandemic and analysis of intervention requirement. International Journal of Health Sciences, 5(3).

https://doi.org/10.53730/ijhs.v5n3.2116 


\section{FULL REGRESSION MODEL 5 Konstruk 12 Indikator}

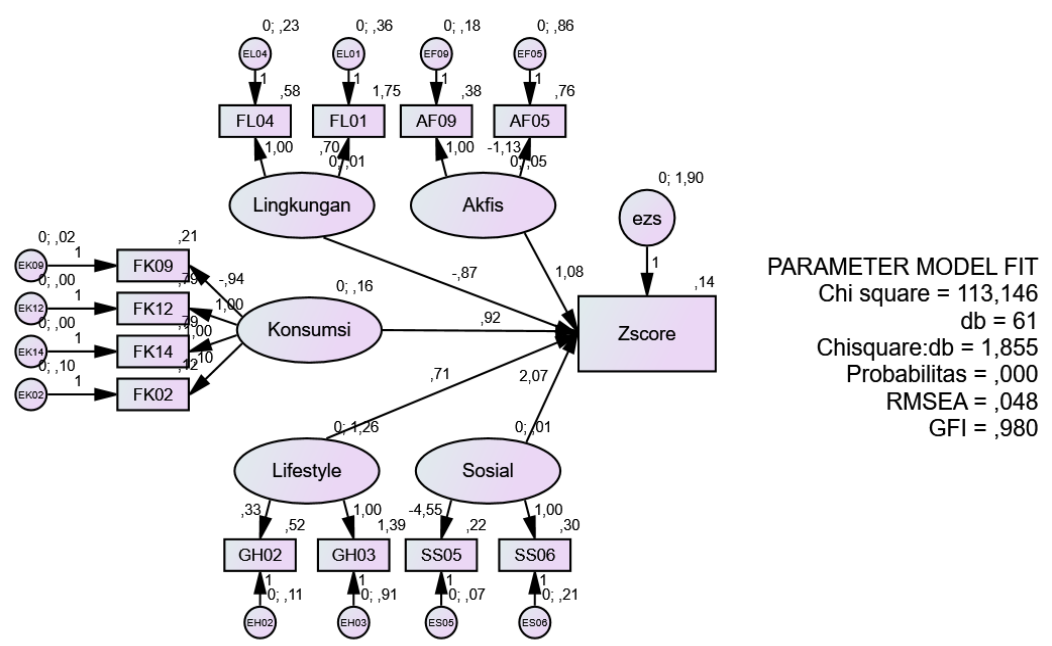

Figure 3. A complete regression model with 5 constructs and 12 indicators

In situations where the chi-square model value is too large, the model fit parameters can be determined based on the relative ratio of the chi-square value to the degree of freedom (chi-square/DB). The model with the lowest chi-square/DB ratio is considered the most reasonable model as long as the fit model parameters other than the chi-square value have met the requirements. Taking this into account, the regression model with 5 constructs and 12 indicators (figure 3) can be considered as the most reasonable model to explain the obesity risk analysis based on consumption factors, physical activity, lifestyle, social and environmental factors, with the contribution of indicators when sorted from large to small can be presented in table 4 .

Table 4

Order of indicators based on regression weights in the fit model of obesity risk analysis

\begin{tabular}{cclc}
\hline No & Code & Indicator & $\begin{array}{c}\text { Regression } \\
\text { weight }\end{array}$ \\
\hline 1 & FK12 & The habit of buying snacks & 0,999 \\
2 & FK14 & The habit of drinking sweet drinks & 0,992 \\
3 & FK09 & Level of liking for vegetables or fruit & 0,928 \\
4 & SS05 & Father/mother ever scolded a child & 0,787 \\
5 & GH03 & Frequency of eating fast food in the past week & 0,763 \\
6 & GH02 & The child ate fast food in the past week & 0,751 \\
7 & AF09 & Other activities that children do while at home & 0,469 \\
8 & AF05 & Duration of children studying outside the home/tutoring & 0,269 \\
9 & FL04 & There is a special sidewalk for pedestrians from home to school & 0,241 \\
10 & SS06 & Children doing sports with family & 0,156 \\
11 & FL01 & The child has been teased/bullied by his friend & 0,138 \\
12 & FK02 & Breakfast Habits & 0,126 \\
\hline
\end{tabular}

As presented in table 4, it appears that the consumption factor has the greatest contribution in increasing the risk of obesity. Three indicators of the consumption construct are the habit of buying snacks; the habit of drinking sugary drinks; and the level of liking for vegetables or fruit ranks at the top if they are sorted by weighting their regression coefficients. In the next order, other factors emerged, namely social factors; lifestyle; physical activity; followed by environmental factors 
Discussion

A poor diet is currently still the main determinant of nutritional problems in Indonesia. When viewed from the consumption pattern of its population, Indonesia has even been included in the category of the obesogenic environment (Hamel, 2001). Based on data released in 2018 the group of foodstuffs that contribute energy per capita per day is still dominated by the grain group (41.11\%); prepared food and beverages (21.09\%); and oil and coconut (12.24\%). The results of the same survey also state that almost all Indonesians (93.6\%) consume fewer vegetables and fruit (Center for Data and Information of the Indonesian Ministry of Health, 2018).

Entering school age, the obesogenic environment that facilitates individuals to become obese is increasingly widespread (Garvey et al., 2016). The school period is a time when children begin to recognize food habits outside the home (Lindström et al., 2006). This is thought to be the driving force behind the rapid development of franchises, especially in the food and beverage sector in Indonesia. In 2018, the turnover of the franchise business in Indonesia reached around 150 trillion IDR and will continue to grow in the future. The contribution came from local and foreign franchises of 2,000 brands (Journalist Koran SIND0, 2019). But unfortunately, this fantastic development has become less favorable for the development of Indonesian children. Foreign franchises that are emerging to the Indonesian market generally come from Taiwan, Japan, South Korea, Malaysia, and Thailand. More than 50 percent of them bring food and beverage products that are not necessarily by the balanced nutrition rules needed by Indonesian children (Rosana, 2019; Agarwal et al., 2012). From the results of the analysis of the structural equation model in this study, it is also evident that most samples (88.3\%) do not have the habit of having breakfast at home, most of them (79.2\%) prefer to eat snacks at school rather than bringing lunch from home, and the existence of franchise outlets that are not by the nutritional needs of children is evidenced by the number of children (78.9\%) who have the habit of drinking sweet drinks.

Given the high risk of being overweight for non-communicable diseases (especially diabetes mellitus and vascular disease), the phenomenon of obesity in children must be prevented as early as possible (SnyderMarlow et al., 2010). Broadly speaking, interventions can be pursued in two ways, namely single intervention, in this case, what is meant is to intervene in dietary changes (dietary interventions) only or changes in physical activity patterns (including sedentary activities), and multi-component interventions, namely intervening diet changes at once. changes in physical activity (Indriasari \& Kurniati, 2017). Modification of eating behavior (dietary intervention only) in this case limiting consumption or intake of certain types of food has proven to be less effective in losing weight, so multicomponent interventions are needed in efforts to prevent obesity (Clark et al., 2014). In the intervention activities carried out on 50 students of SMAN 80 Jakarta, Gifari et al. (2020), proved that multicomponent interventions (nutrition education and increased physical activity) were proven to be able to achieve the goal of efforts to improve nutrition more optimally (Gifari et al., 2020).

All program planners should be aware that those who are currently in elementary school (SD) are those born after 2010. This era is a time when the development of the digital world has almost reached its peak. So you could say that the ability to digitize has been innate to elementary school students since they were born. (Wikipedia Indonesia, 2020). This is certainly a challenge for anyone who wants to create a "program" with school students as the target. Conventional programs will be rejected outright by them. It is necessary to make new innovative breakthroughs so that they can reach them as a whole. This is in line with Laksono (2014), who concluded that inevitably all fields must follow digital trends if they do not want to be out of date, especially in the health sector related to communication problems or delivering information to the public. Several studies or research that has been conducted on the contribution of social media to the health sector has discussed a lot about the potential of social media, the availability of information, support for certain disease patients, its effectiveness in delivering information, or discourse on a particular topic (Laksono \& Hargono, 2014).

Suiraoka, I. P., Nursanyoto, H., \& Suastiti, N. M. A. (2021). Determinant of child obesity in COVID-19 pandemic and analysis of intervention requirement. International Journal of Health Sciences, 5(3). https://doi.org/10.53730/ijhs.v5n3.2116 


\section{Conclusion}

From the results and discussion, the following conclusions can be drawn:

1) From the results of anthropometric examinations of 375 elementary school children in the city of Denpasar, it is known that there are $35.5 \%$ are overweight and $12.3 \%$ are obese. This figure is still above the prevalence of obesity in elementary school children according to the basic health research, $2018(21.8 \%)$.

2) Consumption factors have the greatest contribution in increasing the risk of obesity. In the next order, other factors emerged, namely social factors; lifestyle; physical activity; followed by environmental factors

\section{Suggestion}

Because the target of obesity prevention efforts is more focused on those who are still in elementary school having an age range of 7-12 years, known as the post-millennial generation (alpha generation), it is necessary to design an application with a digital platform to reach them. The digital platform application is also the embodiment of a multicomponent intervention which is one of the prerequisites for the success of nutrition improvement efforts

\section{Acknowledgments}

This work was supported by the Research Fund provided by Poltekkes Kemenkes Denpasar and we are grateful to two anonymous reviewers for their valuable comments on the earlier version of this paper. 


\section{References}

Adhianto, G., \& Soetjiningsih, S. (2002). Prevalence and risk factors of overweight and obesity in adolescents. Paediatrica Indonesiana, 42(9-10), 206-11.

Agarwal, E., Ferguson, M., Banks, M., Bauer, J., Capra, S., \& Isenring, E. (2012). Nutritional status and dietary intake of acute care patients: results from the Nutrition Care Day Survey 2010. Clinical nutrition, 31(1), 4147. https://doi.org/10.1016/j.clnu.2011.08.002

Baker, J. L., Olsen, L. W., \& Sørensen, T. I. (2007). Childhood body-mass index and the risk of coronary heart disease in adulthood. New England journal of medicine, 357(23), 2329-2337.

Barlow, K. M., \& Minns, R. A. (2000). Annual incidence of shaken impact syndrome in young children. The Lancet, 356(9241), 1571-1572. https://doi.org/10.1016/S0140-6736(00)03130-5

Berhman, R. E. (1999). Home visiting: Recent program evaluations. The Future of Children, 9(1).

Beuther, D. A., Weiss, S. T., \& Sutherland, E. R. (2006). Obesity and asthma. American journal of respiratory and critical care medicine, 174(2), 112-119.

Chaput, J. P., Klingenberg, L., Astrup, A., \& Sjödin, A. M. (2011). Modern sedentary activities promote overconsumption of food in our current obesogenic environment. Obesity reviews, 12(5), e12-e20.

Clark, A. L., Fonarow, G. C., \& Horwich, T. B. (2014). Obesity and the obesity paradox in heart failure. Progress in cardiovascular diseases, 56(4), 409-414. https://doi.org/10.1016/j.pcad.2013.10.004

Damayanti, I. L. (2008). Is the younger the better? Teaching English to young learners in the Indonesian context. EDUCARE, 1(1).

Daniels, S. R., Greer, F. R., \& Committee on Nutrition. (2008). Lipid screening and cardiovascular health in childhood. Pediatrics, 122(1), 198-208.

French, S. A., Story, M., \& Perry, C. L. (1995). Self-esteem and obesity in children and adolescents: a literature review. Obesity research, 3(5), 479-490.

Garvey, W. T., Hurley, D. L., \& Kushner, R. F. (2016). Patient-centered care of the patient with obesity. Endocrine Practice, 22, 9-10. https://doi.org/10.4158/1934-2403-22.s7.1

Gifari, N., Nuzrina, R., Ronitawati, P., Sitoayu, L., \& Kuswari, M. (2020). Edukasi Gizi Seimbang dan Aktivitas Fisik dalam Upaya Pencegahan Obesitas Remaja. JMM (Jurnal Masyarakat Mandiri), 4(1), 55-62.

Hamel, W. J. (2001). The effects of music intervention on anxiety in the patient waiting for cardiac catheterization. Intensive and critical care nursing, 17(5), 279-285. https://doi.org/10.1054/iccn.2001.1594

Heird, W. C. (2002). Parental feeding behavior and children's fat mass.

Indriasari, R., \& Kurniati, Y. (2017). Literature Review: Perubahan Gaya Hidup Sebagai Upaya Manajemen Sindroma Metabolik Pada Remaja. Gizi Indonesia, 40(1), 9-20.

Isenring, E. A., Banks, M., Ferguson, M., \& Bauer, J. D. (2012). Beyond malnutrition screening: appropriate methods to guide nutrition care for aged care residents. Journal of the Academy of Nutrition and Dietetics, 112(3), 376-381. https://doi.org/10.1016/j.jada.2011.09.038

Kasiman, S. (2011). Pengaruh makanan pada sindrom metabolik. Indonesian Journal of Cardiology, 24-26.

Kovacs, C. S., Seshiah, V., Swallow, R., Jones, R., Rattunde, H., Woerle, H. J., ... \& EMPA-REG PIO ${ }^{\text {TM }}$ trial investigators. (2014). Empagliflozin improves glycaemic and weight control as add-on therapy to pioglitazone or pioglitazone plus metformin in patients with type 2 diabetes: a 24 -week, randomized, placebo-controlled trial. Diabetes, Obesity and Metabolism, 16(2), 147-158.

Kusumajaya, A. A. N. (2021). Individual and social environmental factor as risk factor of BMI-for-age in school children. International Journal of Health Sciences, 5(2), 89-98. https://doi.org/10.29332/ijhs.v5n2.1242

Laksono, A. D. (2014). Cigarettes in YouTube, in Pros-Cons Cigarette Discourse in YouTube, R. Hargono and $A D$ Laksono, Eds. Jogjakarta: PT Kanisius, 133-148.

Laksono, A. D. (2014). Efektivitas Media Sosial untuk Promosi Kesehatan.

Lindström, J., Ilanne-Parikka, P., Peltonen, M., Aunola, S., Eriksson, J. G., Hemiö, K., ... \& Finnish Diabetes Prevention Study Group. (2006). Sustained reduction in the incidence of type 2 diabetes by lifestyle intervention: follow-up of the Finnish Diabetes Prevention Study. The Lancet, 368(9548), 1673-1679. https://doi.org/10.1016/S0140-6736(06)69701-8

Ningsih, S., Ismail, D., \& Indriani, I. (2021). Study protocol: relationship between parenting patterns and diet with nutritional status of toddlers during COVID-19 pandemic. International Journal of Health Sciences, 5(2), 128-134. https://doi.org/10.29332/ijhs.v5n2.1336

Suiraoka, I. P., Nursanyoto, H., \& Suastiti, N. M. A. (2021). Determinant of child obesity in COVID-19 pandemic and analysis of intervention requirement. International Journal of Health Sciences, 5(3). https://doi.org/10.53730/ijhs.v5n3.2116 
Power, C. (1997). Lake JK, and Cole TJ. Measurement and long-term health risks of child and adolescent fatness. Int J Obes Relat Metab Disord, 21, 507-512.

Pusat Data dan Informasi Kemenkes RI. (2018). Konsumsi Makanan Penduduk Indonesia. Infodatin, hal. 5-7.

Reilly, J. J., \& Dorosty, A. R. (1999). Epidemic of obesity in UK children. The Lancet, 354(9193), 1874-1875. https://doi.org/10.1016/S0140-6736(99)04555-9

Rosana, F. C. (2019). Asosiasi Franchise Keluhkan Asing Kuasai Pasar Waralaba di RI.

Skinner, A. C., \& Foster, E. M. (2013). Systems science and childhood obesity: a systematic review and new directions. Journal of obesity, 2013.

Snyder-Marlow, G., Taylor, D., \& Lenhard, M. J. (2010). Nutrition care for patients undergoing laparoscopic sleeve gastrectomy for weight loss. Journal of the American Dietetic Association, 110(4), 600-607. https://doi.org/10.1016/j.jada.2009.12.022

Vanderhoof, J. A., \& Langnas, A. N. (1997). Short-bowel syndrome in children and adults. Gastroenterology, 113(5), 1767-1778. https://doi.org/10.1053/gast.1997.v113.pm9352883

Whitaker, R. C., Wright, J. A., Pepe, M. S., Seidel, K. D., \& Dietz, W. H. (1997). Predicting obesity in young adulthood from childhood and parental obesity. New England journal of medicine, 337(13), 869-873.

Widana, I.K., Sumetri, N.W., Sutapa, I.K., Suryasa, W. (2021). Anthropometric measures for better cardiovascular and musculoskeletal health. Computer Applications in Engineering Education, 29(3), 550561. https://doi.org/10.1002/cae.22202

Wikipedia Indonesia. (2020). Generasi Z. https://en.wikipedia.org/wiki/Generation_Z

Yoga, P., \& Sidiartha, I. G. L. (2010). Prevalence and Characteristics of Childhood Obesity in Pediatrics Outpatient Clinic. Sanglah Hospital Denpasar.

\section{Biography of Authors}

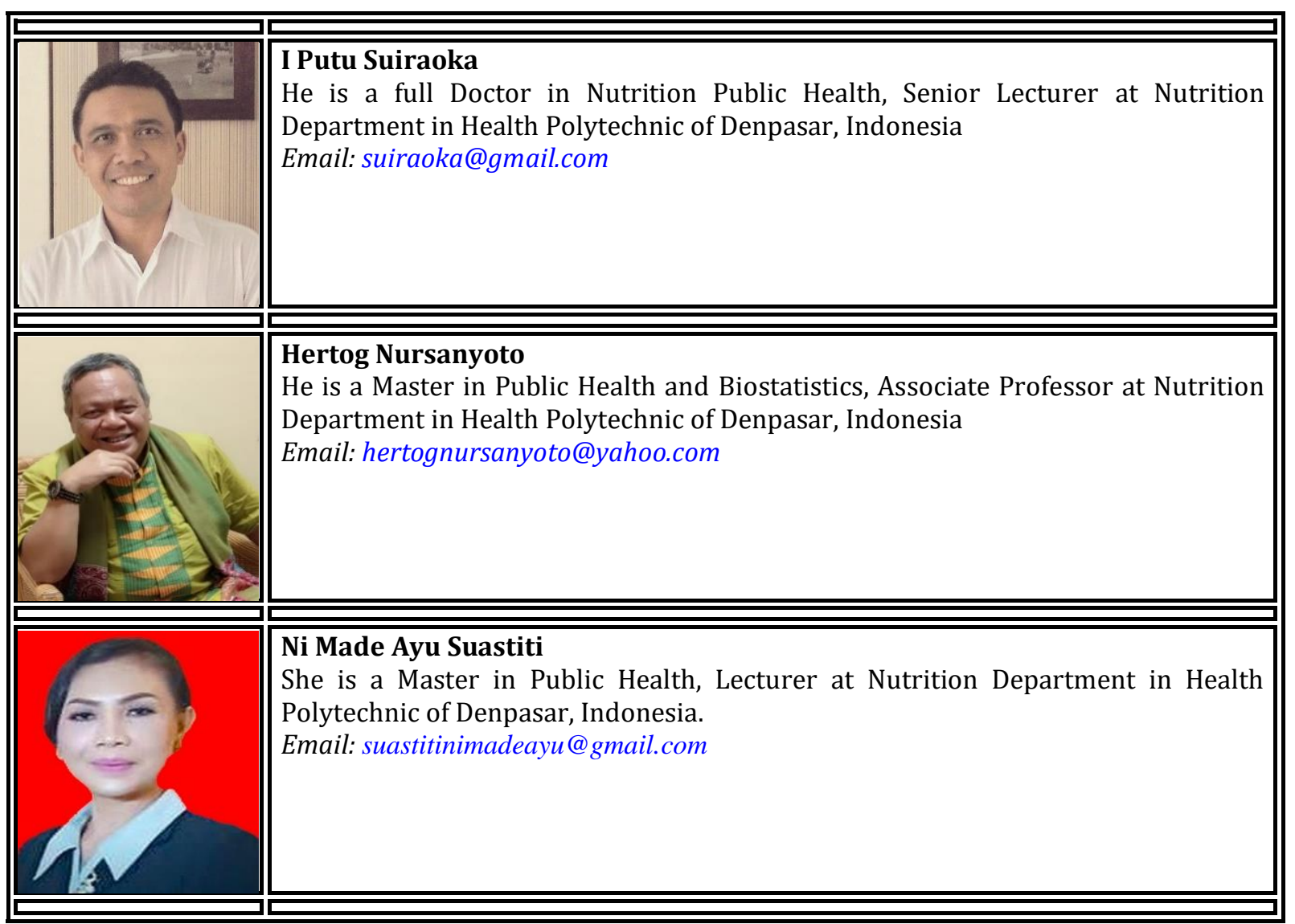

